\title{
INFLUENCE OF MECHANICAL-THERMAL TREATMENT ON THE MICROSTRUCTURE AND CURRENT-CARRYING CAPACITY OF Nb-Ti-SUPERCONDUCTOR
}

\author{
G.E. Storozhilov, N.F. Andrievskaya, M.A. Tikhonovsky \\ National Science Center "Kharkov Institute of Physics and Technology”, Kharkiv, Ukraine \\ E-mail: storozhilov@kipt.kharkov.ua
}

A correlation between the modes of mechanical-thermal treatment, main microstructure parameters and the critical current density $J_{c}$ in the superconducting alloy $\mathrm{Nb}-49 \mathrm{wt} . \% \mathrm{Ti}$ was established. The studies were carried out on the alloy that was preliminary deformed by the "upsetting-extrusion" severe plastic deformation (SPD) method and subsequently drawn with multiple intermediate heat treatments (HT) at $390{ }^{\circ} \mathrm{C}$ for 400 and 2000 h. After completion of the heat treatments, the superconductor was finally drawn with the degree of deformation $e_{f i n}$. It was shown that the volume fraction of $\alpha$-Ti phase precipitates increases with the increasing in number of heat treatments up to $\approx 24$ and $27 \%$ for a total heat treatment duration of 400 and 2000 hours, respectively, and reaches maximum values at HT quantity of $4 \ldots 5$ and 7 . The highest critical current density level in a magnetic field $5 \mathrm{~T}, J_{c} \approx 3.8 \cdot 10^{5} \mathrm{~A} / \mathrm{cm}^{2}$, was obtained for a total heat treatments duration of $2000 \mathrm{~h}, 7$ number of HT and final true strain $\approx 5.05$. The dependence of the pinning volume force $F_{p}$ on the reduced magnetic field $b$ in such superconductor is described by a function in form $F_{p} \sim b(1-b)^{2}$, a characteristic of superconducting materials with strong vortex magnetic lattice on the precipitates.

\section{INTRODUCTION}

Superconductors based on niobium-titanium alloys belong to the mostly used class of superconducting materials [1-3]. The main advantage of these superconductors is the relative simplicity of manufacture (mainly, due to the high ductility of the alloys), high mechanical properties and satisfactory quantity of critical current density $J_{c}$ in magnetic fields (up to $8 \mathrm{~T}$ ). Only the $J_{c}$ value depends strongly on the structural state of the material between the three main technical characteristics of superconductor - critical temperature $T_{c}$, upper critical field $H_{c 2}$ and critical current density $J_{c}$. It should be noted that this characteristic substantially determines the possibility of using a superconductor in the manufacture of specific magnetic systems. Therefore, the main attention of niobium-titanium superconductors' developers is focused on optimizing the microstructure of the alloys in order to create an effective system of pinning centers of magnetic field vortices and, as a result, to achieve the high values of $J_{c}$.

During the longitudinal researches, it was established [4-7], that the most effective pinning centers in niobium-titanium technical superconductors are $\alpha$ titanium precipitates formed during the decomposition (aging) of supersaturated solid solution (metastable $\beta$ phase). Large volume fraction of $\alpha$-Ti precipitation, located uniformly in the superconductor and had a narrow size distribution, has to be necessarily ensured during the metastable $\beta$-phase decomposition in order to achieve the high critical current densities [8-10]. The decomposition of the supersaturated solid solution in $\mathrm{Nb}$-Ti system occurs at relatively low homological temperatures $(\approx 0.3)$ so as its rate is quite low. Various methods are used to accelerate the decomposition process - severe plastic deformation (SPD), deformation at cryogenic temperatures $[11,12]$, etc. Final deformation (drawing) of the superconductor with the optimal overall reduction ratio is used at the end of the processing, after the aging, in order to achieve the desired shape and size of the $\alpha$-Ti precipitates. However, even with the use of "stimulating" treatments, such as SPD or prolonged "aging" heat treatment (HT), it is not possible to implement a fully decomposition process and achieve the optimal volume fraction of $\alpha$-Ti phase precipitations. For example, in [13] it was established that in the $\mathrm{Nb}$ 48.5 wt.\% Ti alloy, subjected to SPD with the degree of "true" (logarithmic) deformation $e_{p r}=7.6$, the volume ratio of the $\alpha$-Ti precipitated after a single $\mathrm{HT}$ at $390{ }^{\circ} \mathrm{C}$ within $2000 \mathrm{~h}$ does not exceed $16 \%$ (volume). In doing so, the decomposition process almost ceases after HT for $400 \mathrm{~h}$. Additional deformation is required for further decomposition stimulation. That is, it is necessary to alternate with the deformation and HT to achieve a large volume fraction of $\alpha$-Ti precipitation. A number of such deformation and HT cycles in the process of obtaining a high-current niobium-titanium superconductor can reach 5 or more. Additionally, it is necessary to optimize the degree of deformation between HT, the HT time and the level of the final deformation.

The aim of this work is to establish the relationship between the number of HT, the main parameters of the microstructure and the critical current density. In this case, the total HT time was set at 400 and $2000 \mathrm{~h}$. The total HT duration in 400 and $2000 \mathrm{~h}$ were chosen due to economic constraints in the industrial production of superconductors and to study prospects of increasing the critical current density in comparison with density, achieved on industrial superconductors, respectively.

\section{EXPERIMENTAL DETAILS}

In this study an ingot of NT-50 alloy (Nb49 wt.\% Ti) with $250 \mathrm{~mm}$ diameter was obtained by vacuum arc melting. The content of the main alloy impurities did not exceed: $\mathrm{C}<0.04, \mathrm{~N}<0.03, \mathrm{O}<0.05$, $\mathrm{Fe}<0.06 \mathrm{wt} . \%$. The grain size in the ingot ranged from 50 to $1375 \mu \mathrm{m}$ (average diameter $d_{m}=535 \mu \mathrm{m}$ ). The ingot was subjected to SPD by the "upsetting-extrusion" method (upsetting and extrusion from $\varnothing 250 \mathrm{~mm}$ to 
$\varnothing 320 \mathrm{~mm}$ and $\varnothing 90 \mathrm{~mm}$, respectively) in order to grind the initial structure and achieve a high degree of preliminary deformation $e_{p r}$ (i.e. deformation before the first heat treatment). The bar obtained after extrusion was placed in a copper cup (case), which was welded with an electron beam in vacuum, as a result, bimetallic assembly was obtained. Then, the assembly was deformed into a bar of $\varnothing 12.5 \mathrm{~mm}$ by extrusion and subsequent drawing. Further routes for producing $\mathrm{Nb}-\mathrm{Ti} / \mathrm{Cu}$ bimetallic wires with a constant total heat treatment time

$t=400 \mathrm{~h}$ are shown in Table 1 . The number of HT varied from 1 to 6 , the deformation between HT was $e_{\text {int }} \approx 0.7$, and the heat treatment temperature was $390{ }^{\circ} \mathrm{C}$. The deformation before the 1st HT $\left(e_{p r}\right)$ varied from 7.0 to 10.7 since the last heat treatment was carried out on the same diameter of $2 \mathrm{~mm}$. The final deformation of the conductors was carried out after the final HT by drawing to various degrees up to $e_{f i n}=5.6$.

Table 1

Routes of the HT in the manufacture of Nb-Ti superconductors for the total time of thermal processing $t=400 \mathrm{~h}$

\begin{tabular}{|c|c|c|c|c|c|c|c|}
\hline Number of HT, $N$ & \multicolumn{6}{|c|}{ The diameter of the wire on which the HT was carried out, mm } & $e_{p r}$ \\
\hline 1 & - & - & - & - & - & 2.0 & 10.7 \\
\hline 2 & - & - & - & - & 2.8 & 2.0 & 10.0 \\
\hline 3 & - & - & - & 4.5 & 2.8 & 2.0 & 9.0 \\
\hline 4 & - & - & 6.1 & 4.5 & 2.8 & 2.0 & 8.4 \\
\hline 5 & - & 9.0 & 6.1 & 4.5 & 2.8 & 2.0 & 7.6 \\
\hline 6 & 12.5 & 9.0 & 6.1 & 4.5 & 2.8 & 2.0 & 7.0 \\
\hline
\end{tabular}

The routes for the manufacture of $\mathrm{Nb}$ - $\mathrm{Ti}$ samples in the case of a total heat treatment time in $2000 \mathrm{~h}$ are given in Table 2. The number of HT varied from 1 to 10,

and the value $e_{\text {int }}$ was $\approx 0.4$. Other parameters of the processing (SPD characteristics, $T, e_{f i n}$ ) are the same as for the samples made with a 400 hours total duration.

Table 2

Routes of the HT in the manufacture of $\mathrm{Nb}$-Ti superconductors for the total time of thermal processing $t=2000 \mathrm{~h}$

\begin{tabular}{|c|c|c|c|c|c|c|c|c|c|c|c|}
\hline \multirow{2}{*}{ Number of HT, $N$} & \multicolumn{8}{|c|}{ The diameter of the wire on which the HT was carried out, mm } & \multicolumn{2}{c|}{$e_{p r}$} \\
\hline 1 & - & - & - & - & - & - & - & - & - & 2.0 & 10.7 \\
\hline 4 & - & - & - & - & - & - & 3.6 & 2.9 & 2.4 & 2.0 & 9.5 \\
\hline 5 & - & - & - & - & - & 4.5 & 3.6 & 2.9 & 2.4 & 2.0 & 9.0 \\
\hline 6 & - & - & - & - & 5.6 & 4.5 & 3.6 & 2.9 & 2.4 & 2.0 & 8.6 \\
\hline 7 & - & - & - & 6.7 & 5.6 & 4.5 & 3.6 & 2.9 & 2.4 & 2.0 & 8.2 \\
\hline 8 & - & - & 8.0 & 6.7 & 5.6 & 4.5 & 3.6 & 2.9 & 2.4 & 2.0 & 7.9 \\
\hline 9 & - & 9.6 & 8.0 & 6.7 & 5.6 & 4.5 & 3.6 & 2.9 & 2.4 & 2.0 & 7.5 \\
\hline 10 & 12.5 & 9.6 & 8.0 & 6.7 & 5.6 & 4.5 & 3.6 & 2.9 & 2.4 & 2.0 & 7.0 \\
\hline
\end{tabular}

The structure of the samples was studied by transmission electron microscopy using a Tesla BS-613 microscope at an accelerating voltage of $100 \mathrm{kV}$ on transverse foils of wires with a diameter of $2 \mathrm{~mm}$. The parameters of $\alpha$-phase particles, released during the heat treatment, - volume fraction $(V)$, average diameter $\left(d_{m}\right)$, density $(\rho)$, coefficient of variation of sizes $\left(k_{v}\right)$ were determined by computer digital image processing of the structure and the following statistical data analysis.

The value of critical currents was measured on wire samples of various sections with a length of $\sim 30 \mathrm{~cm}$, in a universal measuring stand in transverse magnetic fields with induction $B=1 \ldots 8 \mathrm{~T}$ at a temperature of $4.2 \mathrm{~K}$. The distance between potential contacts was $\approx 10 \mathrm{~cm}$. The criterion for recording the critical current was the appearance of a potential difference of $1 \mu \mathrm{V} / \mathrm{cm}$. The critical current density $J_{c}$ was calculated for the cross section of the $\mathrm{Nb}-\mathrm{Ti}$ alloy, i.e. excluding the area of the copper stabilizer. When removing the dependences $J_{c}\left(e_{f i n}\right)$, the maximum value of the critical current density for each HT route was determined (see Table 1 and Table 2), which was designated as $J_{c \max }$.

\section{RESULTS AND DISCUSSION}

Heat treatment with a total duration of $t=400 \mathrm{~h}$. In the manufacture of modern $\mathrm{Nb}$-Ti superconductors of various designs, the critical current density level at $\sim\left(3.0 \cdot 10^{5} \ldots 3.5 \cdot 10^{5}\right) \mathrm{A} / \mathrm{cm}^{2}(B=5 \mathrm{~T})$ is often required, accordingly to the technical specifications. Such level of $J_{c}$ can be achieved by conducting multiply HT at $T=390$ ${ }^{\circ} \mathrm{C}$ for a total of $\approx 400$ hours. Moreover, it is relevant to determine the optimal amount of HT to achieve the required level of $J_{c}$. In this section, the results of studying the effect of the HT number on the structure and, therefore, on the current-carrying capacity of $\mathrm{Nb}$ - $\mathrm{Ti}$ alloy at the mentioned values of total time and temperature of HT are presented. 

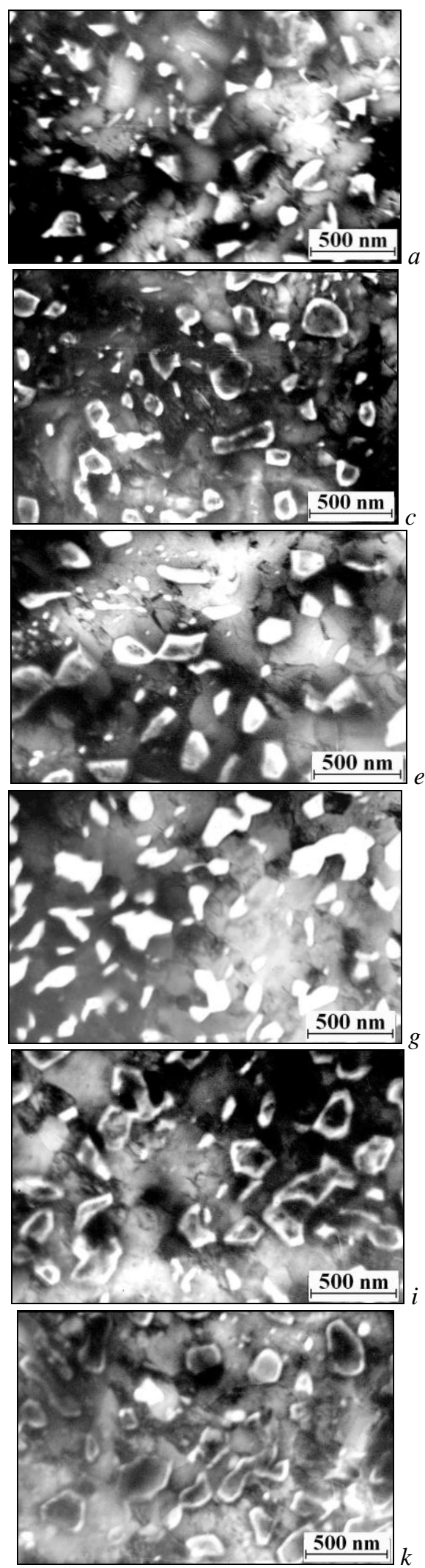
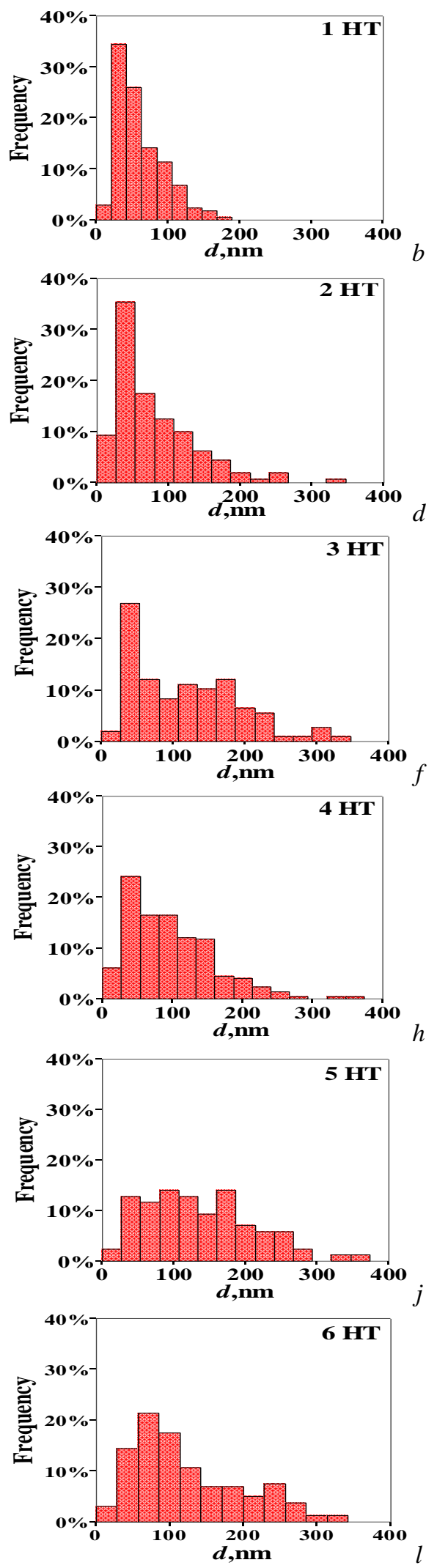

Fig. 1. The microstructure of Nb-Ti superconductors after the final HT $(t=400 \mathrm{~h})$ and the corresponding histograms of the size distribution of the $\alpha$-Ti phase precipitates at $N=1(a, b) ; N=2(c, d) ; N=3(e, f) ; N=4(g, h)$; $N=5(i, j) ; N=6(k, l)$. Heat treatment routes corresponding to $N$ values are given in Table 1

Two-phase microstructure of Nb-Ti superconductors after the final HT (at $\varnothing=2 \mathrm{~mm}$ ) and size distribution histogram of the $\alpha$-Ti precipitation are shown in Fig. 1.
During increasing the number of HT from 1 to 6 , a gradual evolution of the distribution of precipitate sizes occurs (see Fig. 1). With a single HT, the microstructure is characterized by the distribution of $\alpha$-Ti particles 
with an increased density of small-sized objects (see Fig. 1,a,b). This fact is a consequence of the high density of the centers of the phase nucleation in the form of the finely dispersed subgrain structure boundaries formed after a high degree of preliminary deformation $e_{p r}=10.7$. The frequency of the small $\alpha$-Ti phase precipitates appearance decreases with an increasing in the amount of HT up to $4 \ldots .5$ and larger objects appear in the distribution (see Fig. 1,g-j). The shape of distribution takes on a flatter form with an approximately equal frequency parameter of precipitate size in the range of $50 \ldots 250 \mathrm{~nm}$. After $6 \mathrm{HT}$, a peak of low-sized precipitates $(\sim 70 \mathrm{~nm})$ starts to form again in the distribution (see Fig. 1,k,l). This is probably due to the minimum duration of each HT (67 hours) and the maximum total intermediate deformation $\left(\Sigma e_{i n t} \sim 3.7\right)$.

The dependences of the main parameters of $\alpha-\mathrm{Ti}$ phase particles on the amount of HT are shown in Fig. 2. The $V(N)$ curve characterized the amount of phase precipitated in the $\mathrm{Nb}-\mathrm{Ti}$ alloy for $t=400 \mathrm{~h}$ case has a maximum at $5 \mathrm{HT}$ of $80 \mathrm{~h}$ each (see Fig. 2,a). The density of released particles decreases with an increase in the amount of HT up to 5 (see Fig. 2,b). A decisive influence on this is exerted by a decreasing value of preliminary deformation, after which a larger subgrain structure with a lower density of nucleation centers of second phase is formed [13]. The emerging process of the precipitate density curve reached saturation is prob-
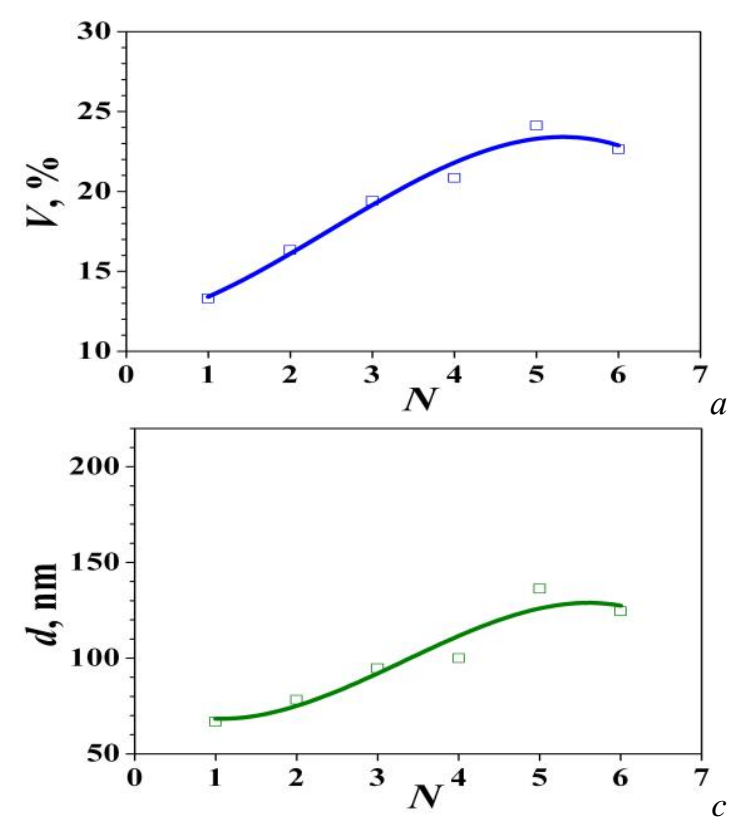

Fig. 2. Dependences of the statistical parameters of the $\alpha$-Ti phase particles on the amount of HT for a total heat treatment time of $400 \mathrm{~h}$

The dependence of the critical current density on the number of heat treatments $J_{c \max }(N)$ (Fig. 3) has a similar character to the $V(N)$ dependence. The maximum value ably associated with the contribution of increasing growth factor of the total value $e_{i n t}$ and a decreasing in the duration of each HT. The dependence of the average size of $\alpha$-Ti phase on the amount of HT (see Fig. 2,c) is characterized by a maximum at $N$ about 5 , which is similar to the $V(N)$ dependence (see Fig. 2,a). Taking into account that with increasing in the amount of HT a decrease in the density of $\alpha-\mathrm{Ti}$ phase precipitates (see Fig. 2,b) is observed, an increase in the $\alpha$-Ti phase volume content with $N$ growth (see Fig. 2,a) is provided due to a more intensive increment the precipitates size (see Fig. 2,c). Moreover, a slight increase in the uniformity of precipitated phase size is taken place with increasing $N$ up to 5 (see Fig. 2,d).

Thus, the limit volume of the precipitated phase, occured due to the influence of the amount of HT at constant values $t, e_{i n t}, T$, is determined by several factors. Firstly, the growth of the preliminary deformation $e_{p r}$ value leads to an increase in $V$ [13]. Secondly, an increase in the total intermediate strain $e_{\text {in }}$ (increase in $N$ ) contributes to the $\alpha$-Ti phase precipitate. Thirdly, the duration of each heat treatment, which decreases with an increase in $N$, lead to a decrease in phase precipitation after each HT. As a result, the optimal ratio of these 3 parameters leads to the greatest $\alpha$-Ti phase precipitation during 5 heat treatments, which was experimentally shown (see Fig. 2,a).
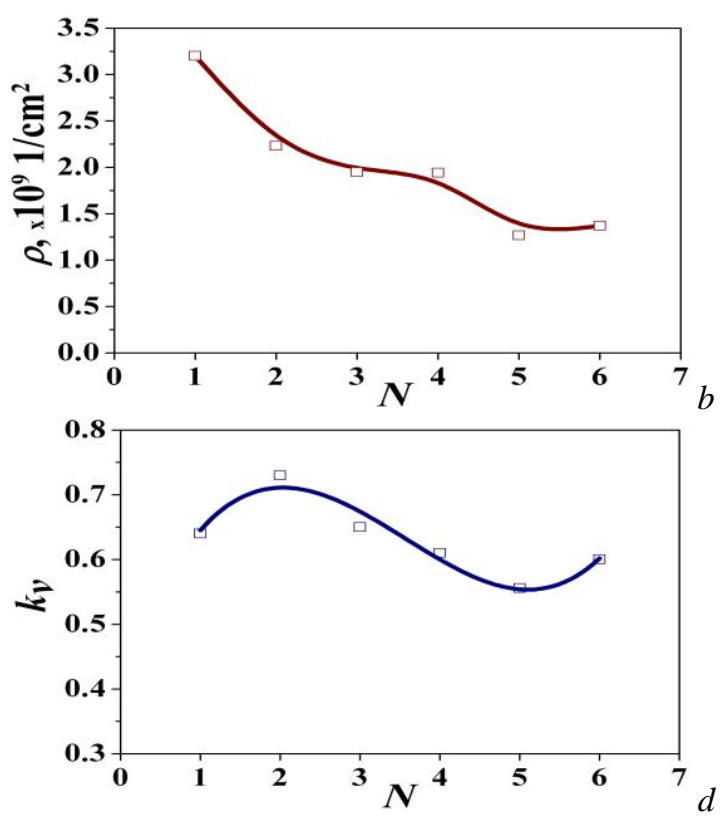

of $J_{c}(5 \mathrm{~T}) \approx 3.6 \cdot 10^{5} \mathrm{~A} / \mathrm{cm}^{2}$ was obtained with optimal parameters of heat treatment number $N=4-5$ and the final strain $e_{f i n}=4.61$. 


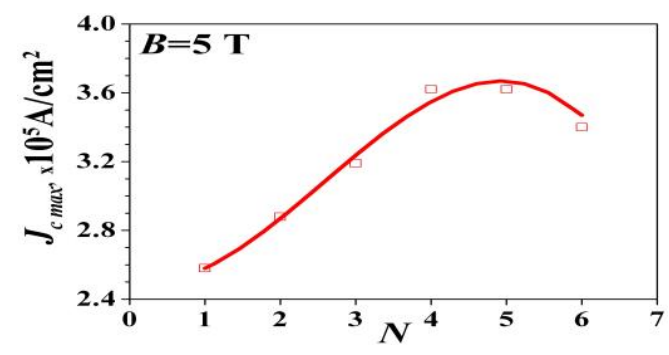

Fig. 3. Dependence of the critical current density of an $\mathrm{Nb}$-Ti superconductor in a field of $B=5 \mathrm{~T}$ at an optimal final deformation $J_{c \text { max }}$ on the number of HT (total heat treatment time $400 \mathrm{~h}$ )

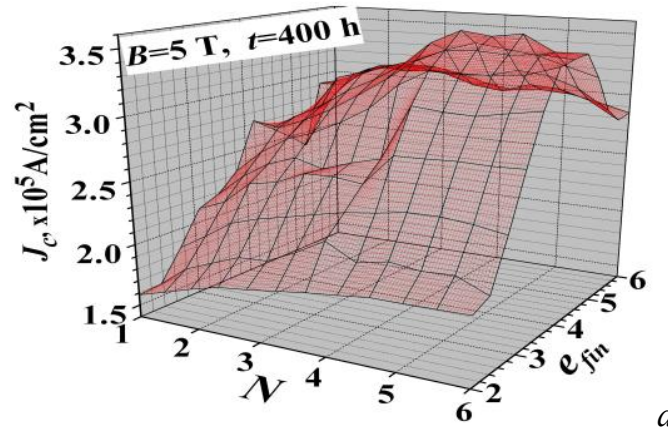

A 3D graph of the $J_{c}-N$ dependence on the final deformation $e_{f i n}$ is shown in Fig. 4,a. The weak dependence of $J_{c}$ on $N$ at small values of $e_{f i n}$ is converted to a strongly pronounced dependence with a high level of $J_{c}$ at large values of $e_{f i n}$. Plot of lines of critical current $J_{c}$ density at varying parameters $N$ and $e_{f i n}$ is shown at Fig. 4,b. Maximum value of $(3.5 \ldots 3.6) \cdot 10^{5} \mathrm{~A} / \mathrm{cm}^{2}$ can be seen from the dependence of the isolines, which is approximately $30 \%$ higher than the maximum level of $J_{c} \approx 2.8 \cdot 10^{5} \mathrm{~A} / \mathrm{cm}^{2}$ obtained by 1 -time heat treatment for $400 \mathrm{~h}$.

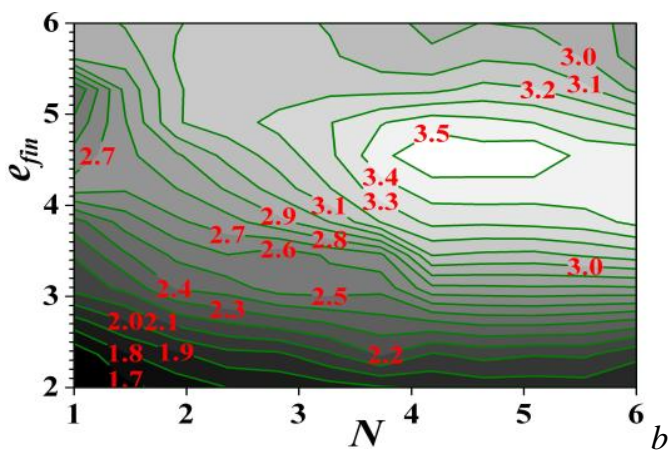

Fig. 4. Dependence of $J_{c}$ for $N b$-Ti superconductor on $N$ and $e_{\text {fin }}(a)$ and graph of isolines $J_{c}(b)$ with a total heat treatment time of $400 \mathrm{~h}$ (magnetic field $B=5 \mathrm{~T}$ )

The dependences of the volume pinning force $F_{p}$ on the reduced magnetic field $b=B / B_{c 2}$ for conductors with different amounts of HT are shown in Fig. 5,a. An increase in the maximum value of $F_{p}$ with an increase in the amount of HT up to 5 and its shift to the region of lower magnetic field are the characteristic features of the obtained curves.

It is known that the shape of the pinning curve $F_{p}(b) \sim b^{m}(1-b)^{n}$ is determined by power coefficients $m$ and $n$. The behavior of these parameters, as well as the position of the peak of the volume pinning force

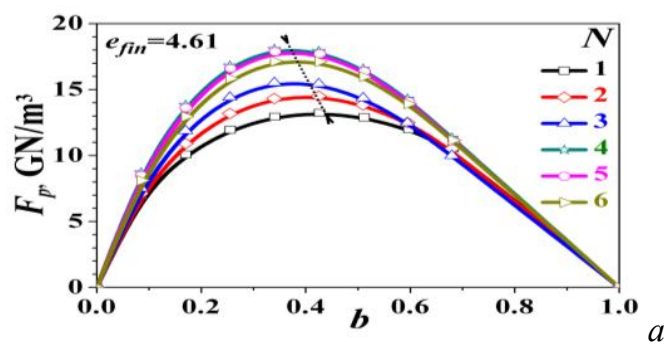

$b_{\max }=m /(m+n)$, is shown in Fig. 5,b for a different number of HT. Analysis of these dependences showed that the $m$ value during $2 \ldots .5$ heat treatments varies little (within $0.75 \ldots 0.85$ ) [14]. However, the $n$ growth is quite significant $(0.8 \ldots 1.3)$. Consequently, the shape of the $F_{p}(b)$ curve is determined mainly by the characteristics of the second phase precipitates. A large volume precipitates fraction of the $\alpha$-Ti phase causes an increase in the coefficient $n$.

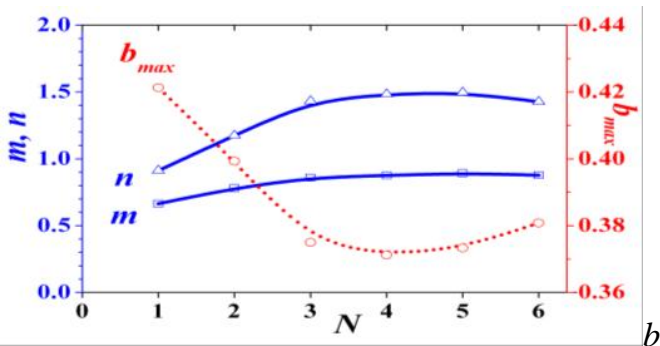

Fig. 5. Field dependences of the pinning force $(a)$ and parameters characterizing the shape of the $F_{p}(b)$ curve for various amounts of HT (b) for the Nb-Ti alloy $(t=400 \mathrm{~h})$

Heat treatment with a total duration of $\boldsymbol{t}=\mathbf{2 0 0 0} \mathbf{h}$. It was shown in [13] that the increase in the volume fraction of the $\alpha$-Ti phase precipitation with an increase in the single HT duration from 400 up to $2000 \mathrm{~h}$ at a value of $e_{p r}=4.0 \ldots 7.6$ averaged about $27 \%$. The estimated calculation of the increasing critical current density at such HT due to increase in the phase volume fraction, carried out according to the formula $J_{c \max }=120 \cdot V+675$ for a magnetic field of $5 \mathrm{~T}$ [15], shows an increase in $J_{c \max }$ by $18 \%$ and achievement of the limit level $J_{\text {max }} \approx 2.6 \cdot 10^{5} \mathrm{~A} / \mathrm{cm}^{2}$ at $t=2000 \mathrm{~h}$. Further enhancement in the decomposition degree and, as a result, an increase in the current carrying capacity of the $\mathrm{Nb}-\mathrm{Ti}$ superconductor can be achieved by conducting multiple HT. Fig. 6 shows electron-microscopic images of the $\mathrm{Nb}$-Ti superconductors $\varnothing=2 \mathrm{~mm}$ structure after repeated HT $(N=1 \ldots 10)$ with a $2000 \mathrm{~h}$ total duration (see Table 2) and the corresponding histograms of the $\alpha$-Ti phase size distribution. 

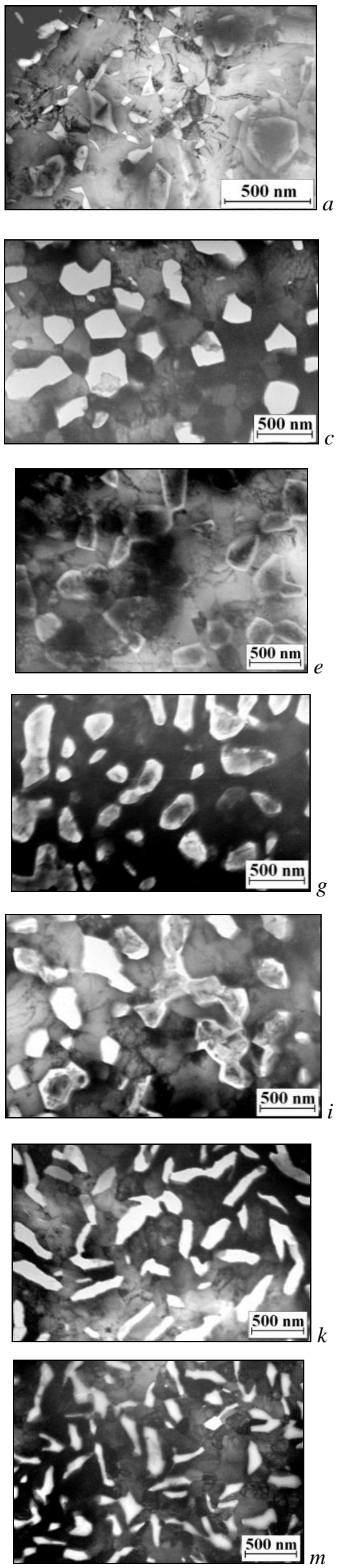
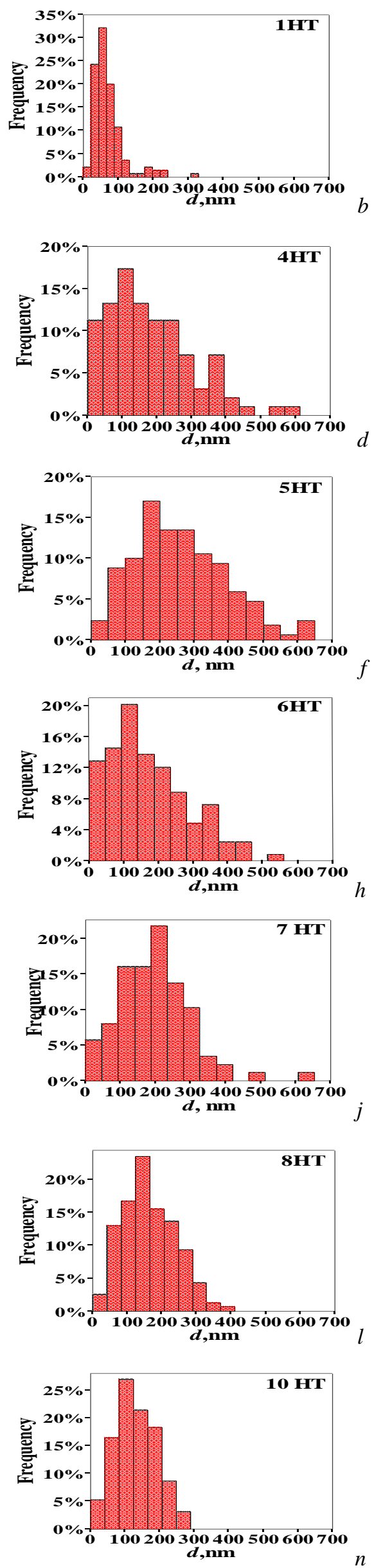

Fig. 6. Microstructure of Nb-Ti superconductors after the final HT and histograms of the size distribution of $\alpha$-Ti phase precipitates at $N=1(a, b) ; 4(c, d) ; 5(e, f) ; 6(g, h) ; 7(i, j) ; 8(k, l,) ; 10(m, n) . t=2000 h$. The heat treatment routes corresponding to the $N$ values are given in Table 2 
The microstructure of $\mathrm{Nb}$-Ti samples after $2000 \mathrm{~h}$ heat treatment, as well as at $400 \mathrm{~h}$, is characterized by a high density of low-sized $\alpha$-Ti phase precipitates at one HT (see Fig. 6,a,b). With an increase in the amount of
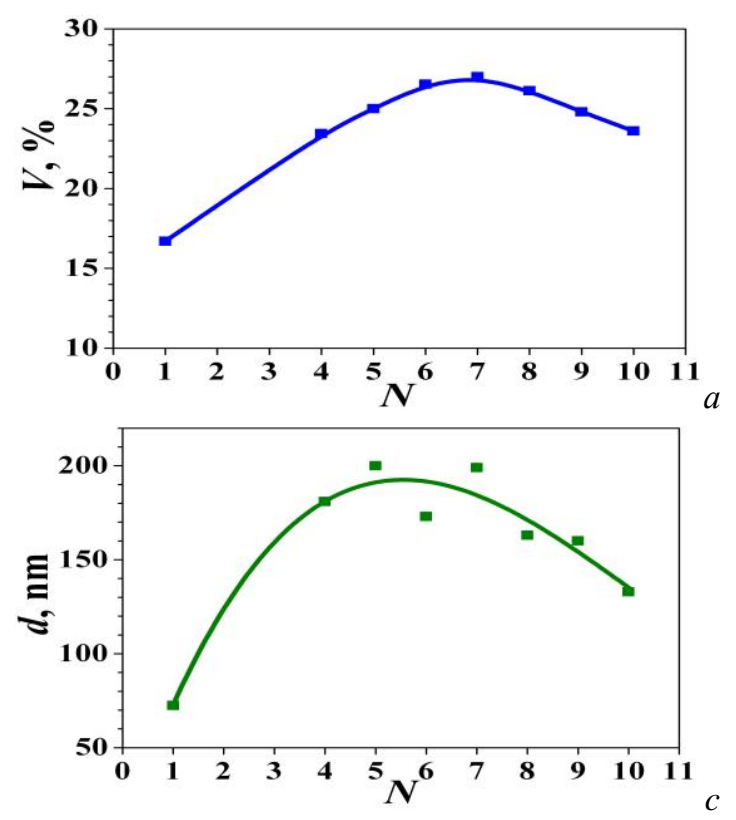

HT up to 7 , a broadening of the phase size distribution on the histogram is observed (see Fig. 6,c-j). The reverse narrowing of the distribution occurs with a subsequent increase in the amount of HT (see Fig. 6,k-n).
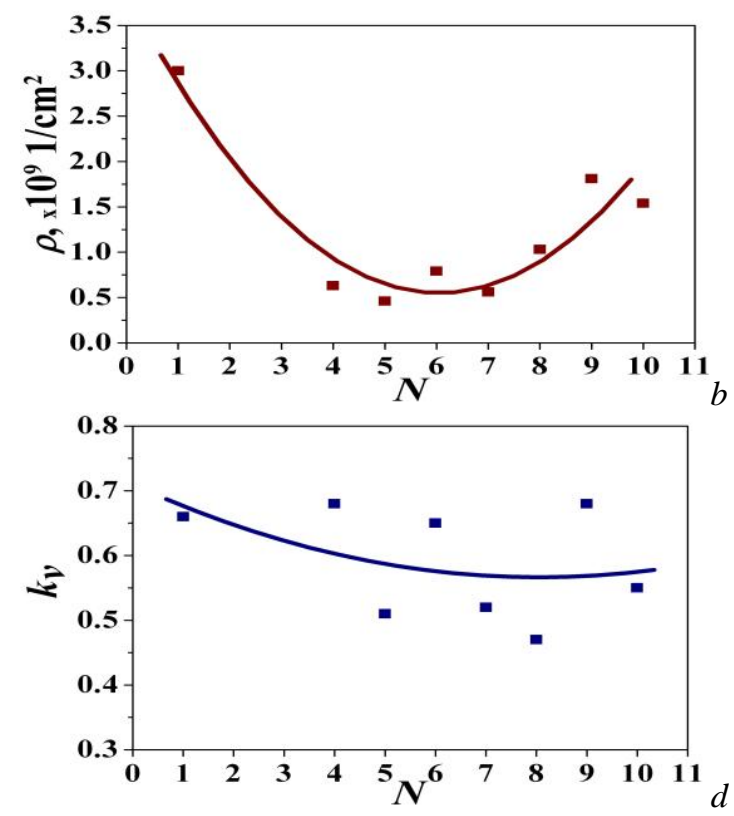

Fig. 7. The dependence of the parameters of the $\alpha$-Ti phase on the number of HT with a total duration of heat treatment of $2000 \mathrm{~h}$

The dependences of the precipitated $\alpha$-Ti phase main parameters on the number of HT with a total duration of $2000 \mathrm{~h}$ is shown on Fig. 7. The curve of $\alpha$-phase volume fraction (see Fig. 7,a) has a similar domed shape, as in the case of $400 \mathrm{~h} \mathrm{HT}$. The difference between these dependences is a shift towards a larger number $N$ and an increase in the maximum value of $V$ with an increase in the total time of HT. The maximum $V$ is reached at $N=7$ and its absolute value is about $27 \%$. The change in the precipitate density has the opposite character (see Fig. 7,b). The precipitate density is minimal $\left(\approx 0.5 \cdot 10^{9} 1 / \mathrm{cm}^{2}\right)$ at optimal $N$ and significantly lower than the particle density in the case of $400 \mathrm{~h}$ HT duration $\left(\approx 1.5 \cdot 10^{9} 1 / \mathrm{cm}^{2}\right)$. The dependence of the average diameter of $\alpha$-Ti phase precipitates on $N$ (see Fig. 7,c), as in the previous case (see Fig. 2,c), is maximum at an optimal value of $N$. The largest average diameter of the $\alpha$-Ti phase reaches $200 \mathrm{~nm}$, which is $50 \%$ higher than at $400 \mathrm{~h}$. Thus, a higher level of the volume fraction of the precipitated phase at $2000 \mathrm{~h} \mathrm{HT}$ is ensured by summing objects of lower density and larger size. The coefficient of precipitated phase sizes variation has a large scatter, however, there is a decrease tendency at the optimal $N$ value, which is similar to 400 h case (see Fig. 7,d).

Although the achieved level of uniformity of precipitate sizes is insufficient, a high level of currentcarrying capacity is achieved in such a superconductor (Fig. 8).

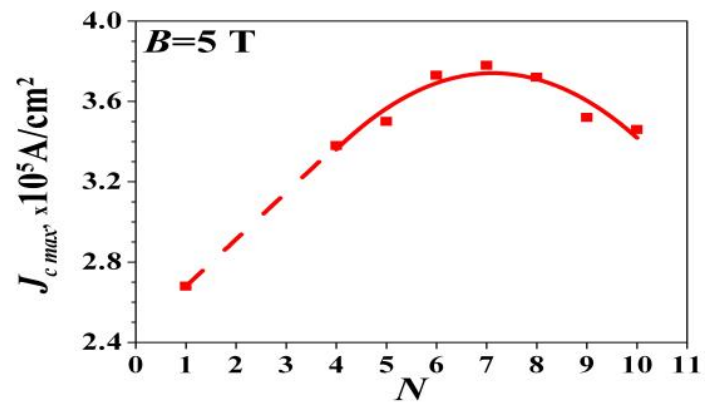

Fig. 8. Dependence of $J_{c \max }(N)$ for $N b$-Ti superconductor with a heat treatment duration of $t=2000 \mathrm{~h}$

The $J_{c \max }(N)$ at $t=2000 \mathrm{~h}$ dependence behavior (see Fig. 8) is similar to curve for $t=400 \mathrm{~h}$ (see Fig. 3) and correlates with the change in the volume fraction of the precipitated $\alpha$-Ti phase (see Fig. 7,a). It can be seen from the Fig. 8, the maximum value of $J_{c \max }$ is observed in the region $N=6 \ldots 8$. Lowering $J_{c \max }$ at $N>8$ may be associated with decrease in $e_{p r}$. The observed maximum values of $J_{c \max }$ at $t=2000 \mathrm{~h}$ in various magnetic fields are $7.4 \cdot 10^{5}, 3.8 \cdot 10^{5}, 1.4 \cdot 10^{5} \mathrm{~A} / \mathrm{cm}^{2}$ at 2,5 , and $8 \mathrm{~T}$, respectively. It should be noted, that the $J_{c \max }$ values are noticeably lower for conductors with $t=400 \mathrm{~h}$ and $N=6\left(6.5 \cdot 10^{5}, 3.6 \cdot 10^{5}, 1.2 \cdot 10^{5} \mathrm{~A} / \mathrm{cm}^{2}\right.$ at 2,5 , and $8 \mathrm{~T}$, respectively). 

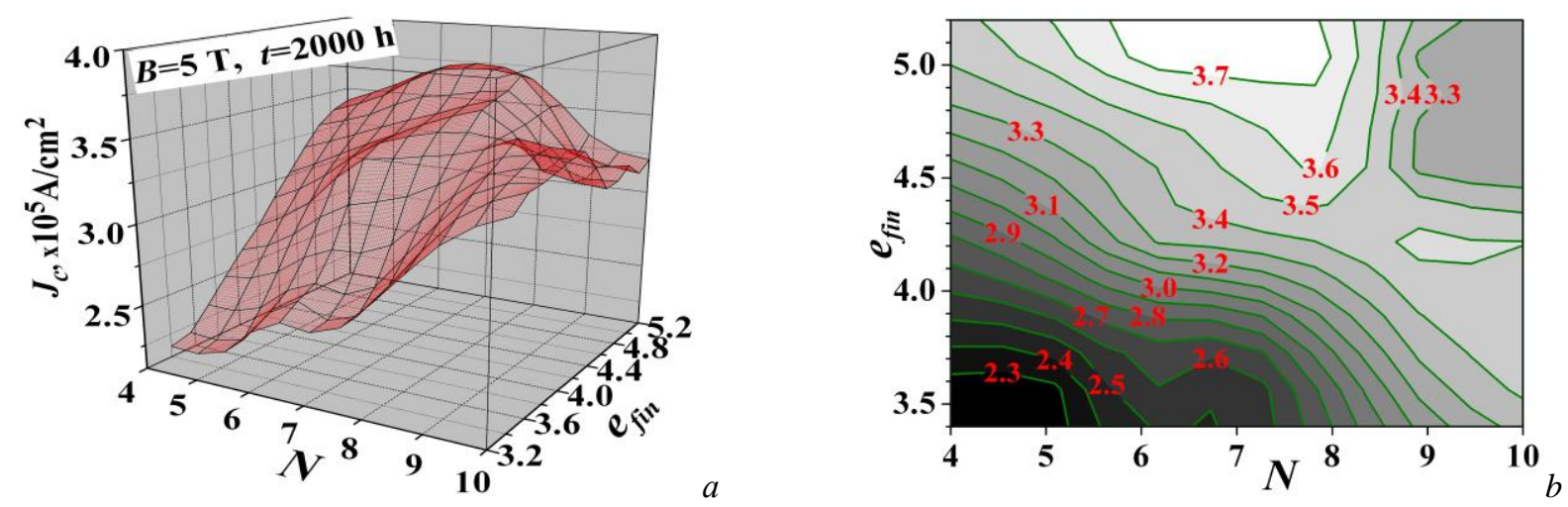

Fig. 9. Dependence of $J_{c}$ for $N b$-Ti superconductor on $N$ and $e_{f i n}(a)$ and graph of isolines $J_{c}(b)$ for a total heat treatment time of $2000 \mathrm{~h}$ (magnetic field $B=5 \mathrm{~T}$ )

The surface of the 3-dimensional dependence $J_{c}\left(N, e_{f i n}\right)$ for a total 2000 hours HT duration is shown on Fig. 9,a. A quite sharp top of the surface is located at the displaced coordinates $N$ and $e_{\text {fin }}\left(N=7\right.$ and $\left.e_{\text {fin }}=5.1\right)$ after $2000 \mathrm{~h}$ heat treatment compared to $N=5$ and $e_{f i n}=4.6$ for $400 \mathrm{~h}$ heat treatment. The formation of the surface geometry and the parameters for reaching the maximum level $J_{\text {c max }} \approx 3.8 \cdot 10^{5} \mathrm{~A} / \mathrm{cm}^{2}$ are clearly visible from the isolines $J_{c}$ dependences (Fig. 9,b).

The volume pinning force dependences on the reduced magnetic field for a different number of HT for the case $t=2000 \mathrm{~h}$ are shown on Fig. 10,a. The maximum pinning ability $F_{p}(b) \approx 19.1 \mathrm{GN} / \mathrm{m}^{2}$ was achieved at $b=0.36(B=4 \mathrm{~T}), N=7, e_{f i n}=5.05$. In the case of a shorter HT time $(400 \mathrm{~h})$, this parameter was $F_{p}(b) \approx 18.2 \mathrm{GN} / \mathrm{m}^{2} \quad$ at $b=0.44 \quad(B=5 \mathrm{~T}), \quad N=5$, $e_{f i n}=4.61$. A higher pinning force shifted to the lowfield region $(b=0.36)$ achieved in a Nb-Ti superconductor with long-term HT is associated with the release of a larger volume fraction of pinning centers $-\alpha-\mathrm{Ti}$ phase precipitation. This maximum value of $F_{p}$ was

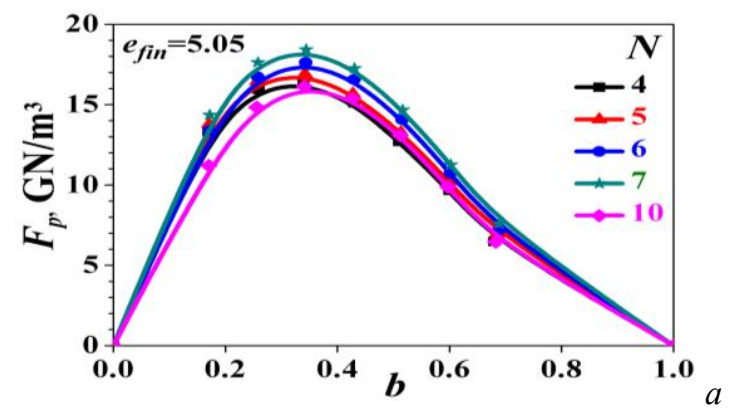

obtained with an increased value of the final deformation $e_{f i n} \approx 5.05$ (at $400 \mathrm{~h} \mathrm{HT}$, the maximum $F_{p}$ is reached at $\left.e_{f i n}=4.61\right)$. An increase in $e_{f i n}$ is necessary to reduce the size of the larger $\alpha$-Ti phase precipitates, which form during long-term HT, thereby, to ensure optimal adjustment of the "precipitation lattice" and the flux-line lattice.

Fig. 10,b characterizes the change in the parameters of the shape of the pinning curves (see Fig. 10,a) depending on $N$ during long-term HT. It can be seen that the value of $m$ slightly increases with increasing $N$, but remains close to 1 , which is higher than in the $t=400 \mathrm{~h}$ case ( $m \approx 0.8$ ). On the average, the value of the coefficient $n$ is close to 2 and is $0.8 \ldots 1.3$ at shorter HT duration. Thus, the shape of the pinning curve for $2000 \mathrm{~h}$ and $400 \mathrm{~h}$ are described by different functional dependences close to $F_{p} \sim b(1-b)^{2}$ and $F_{p} \sim b(1-b)$, respectively. Consequently, the nature of the $F_{p}$ curve is mainly associated with the completeness of supersaturated solid solution. A higher amount of $\alpha$-Ti phase corresponds to an increased coefficient $n$.

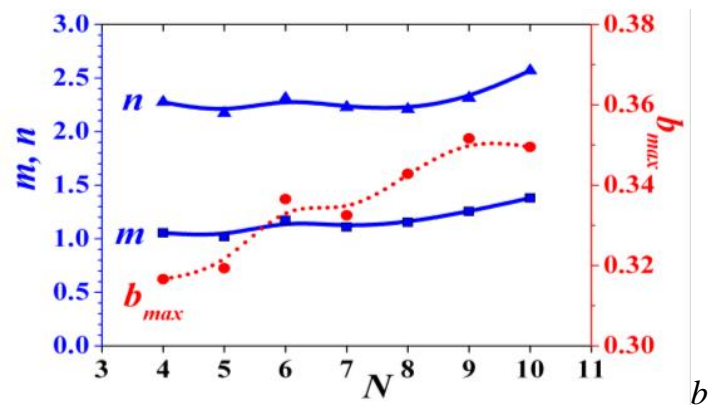

Fig. 10. Field dependence of pinning force $(a)$ and curve shape parameters $F_{p}(b)$ for a different number of HT's with a total duration of $2000 \mathrm{~h}$

\section{CONCLUSION}

1. It was shown for a technical superconducting alloy $\mathrm{Nb}-49$ wt. $\% \mathrm{Ti}$ that the volume fraction $\alpha$-Ti phase precipitation $V$ increases up to $V \approx 24 \%$ and $V \approx 27 \%$ with increasing in multi-stage mechanical heat treatments number with a total heat treatment time $t=400$ and $t=2000 \mathrm{~h}$, respectively, reaching maximum values at $N=4 \ldots .5(t=400 \mathrm{~h})$ and $N=7(t=2000 \mathrm{~h})$.

2 . The volume content of the $\alpha$-Ti phase increases with increase in the number of thermal treatments up to the optimum level, which is ensured by a more intensive increment in the precipitate size with decreasing density.

3. The dependence of the critical current density, $J_{c}$, on the number of heat treatments $J_{c}(N)$ is similar to the dependence of the volume fraction $\alpha$-Ti phase precipitates $V(N)$. Moreover, the $J_{c}$ value is proportional to the volume fraction of precipitates.

4. The highest critical current density level in a magnetic field of $5 \mathrm{~T}$ is $J_{c \max }(5 \mathrm{~T}) \approx 3.6 \cdot 10^{5} \mathrm{~A} / \mathrm{cm}^{2}$ and $J_{c \max }(5 \mathrm{~T}) \approx 3.8 \cdot 10^{5} \mathrm{~A} / \mathrm{cm}^{2}$ for a total heat treatment time of 400 and $2000 \mathrm{~h}$, correspondingly. These values 
were achieved with the following optimal values of heat treatments number, $N$, and final deformation, $e_{f i n}$ : $N=4 \ldots .5, e_{f i n}=4.61$ for $t=400 \mathrm{~h}$ and $N=7, e_{f i n}=5.05$ for $t=2000 \mathrm{~h}$. The indicated values of the critical current density are at the level of the best world manufacturers or surpass them.

5. The dependence of the volume pinning force, $F_{p}$, on the reduced magnetic field, $b$, in a superconductor with a maximum critical current density is described by a function in the $F_{p} \sim b(1-b)^{2}$ form, which is a feature of superconducting materials with strong pinning of the vortex magnetic lattice on precipitates.

\section{REFERENCES}

1. Assembly of CMS magnet begins // CERN Courier. 1999, v. 39, N 9, p. 7.

2. A.K. Shikov, A.D. Nikulin, A. Silaev, A. Vorobieva, V.I. Pantsyrnyi, G.P. Vedernikov, N.I. Salunin, S. Sudiev. Development of the superconductors for ITER magnet system // J. Nucl. Mater. 1998, v. 258-263, pt. B, p. 1929-1934.

3. D.E. Andrews. Magnetic resonance imaging in 1987 // Adv. Cryog. Eng. 1988, v. 33, p. 1-7.

4. J.B. Vetrano, R.W. Boom. High critical current superconducting titanium-niobium alloy // J. Appl. Phys. 1965, v. 36, p. 1179-1180.

5. I. Pfeiffer, H. Hillmann. Der Einfluss der Struktur auf die Supraleitungseigenschaften von NbTi50 und NbTi65 // Acta Metall. 1968, v. 16, p. 1429-1439.

6. D.C. Larbalestier. Niobium-titanium superconducting materials, Chapter 3 of Superconductor Materials Science / S. Foner, B.B. Schwartz, eds. Plenum Press, New York, 1981, p. 133-199.

7. O.V. Chernyj, G.F. Tikhinskij, G.E. Storozhilov, M.B. Lasareva, L.A. Kornienko, N.F. Andrievskaya, V.V. Slezov, V.V. Sagalovich, Ya.D. Starodubov, S.I. Savchenko. Nb-Ti superconductors of a high current-currying capacity // Superconductors Science and Technology. 1991, v. 4, p. 318-323.

8. P.J. Lee, P.J. McKinnell, D.C. Larbalestier. Re- stricted Novel Heat Treatments for Obtaining High $\mathrm{J}_{\mathrm{c}}$ in Nb-46.5wt.\%Ti // Advances in Cryogenic Engineering (Materials). 1990, v. 36, p. 287-294.

9. Г.Е. Сторожилов, И.Н. Шаповал, О.В. Черный, Н.Ф. Андриевская. Изучение распределения размеров структуры при термомеханической обработке ниобий-титанового сплава // ВАНТ. Серия «Вакуум, чистые материаль, сверхпроводники». 2006, №1(15), с. 67-71,

10. Г.Е. Сторожилов, Н.Ф. Андриевская, М.А. Тихоновский, М.П. Старолат, И.Н. Шаповал, И.Н. Белошенко, Н.И. Матросов, В.В. Чишко. Процессы структурообразования в сверхпроводящем сплаве НТ-50 при комбинированном воздействии различных видов ИПД // Физика и техника высоких давлений. 2011, т. 21, №1, с. 102-111.

11. O.V. Chernyi, V.K. Aksenov, O.I. Volchok, G.E. Storozhilov, N.F. Andrievskaya, N.F. Starodubov, M.B. Lazareva, L.G. Udov. The effects of low temperature deformation on the microstructure and $\mathrm{J}_{\mathrm{c}}$ of $\mathrm{Nb}$-49Ti superconductor // Czechoslovak. Journal of Physics. 1996, v. 46, suppl. S6, p. 3383-3384.

12. О.И. Волчок, М.Б. Лазарева, А.В. Мац, Я.Д. Стародубов, Н.А. Черняк, О.В. Черный. Влияние низкотемпературной деформации на деградацию критического тока сверхпроводящего сплава Nb-Ti // Физика низких температур. 2005, т. 31, №10, с. 1171-1176.

13. Г.Е. Сторожилов, Н.Ф. Андриевская, М.А. Тихоновский. Диффузионный распад интенсивно деформированного $\mathrm{Nb}$-Ті-сплава // ФММ. 2014, т. 115, №5, с. 756-762.

14. H. Hillmann, K.J. Best. New measurements of critical data of optimized NbTi superconductors // IEEE Trans. Mag. 1977, MAG-13, p. 1568-1570.

15. P.J. Lee. Abridged metallurgy of ductile alloy superconductors // Wiley Encyclopedia of Electrical and Electronics Engineering. New York: Wiley, 1999, v. 21, p. $75-87$.

Article received 27.11.2019

\title{
ВЛИЯНИЕ МЕХАНИКО-ТЕРМИЧЕСКОЙ ОБРАБОТКИ НА МИКРОСТРУКТУРУ И ТОКОНЕСУЩУЮ СПОСОБНОСТЬ Nb-Тi-СВЕРХПРОВОДНИКА
}

\author{
Г.Е. Сторожилов, Н.Ф. Андриевская, М.А. Тихоновский
}

Установлена взаимосвязь между режимами механико-термической обработки, основными параметрами микроструктуры и плотностью критического тока $J_{c}$ в сверхпроводящем сплаве $\mathrm{Nb}-49$ мас.\% Ті. Исследования проведены на сплаве, который подвергался предварительной интенсивной пластической деформации (ИПД) методом «осадки-выдавливания» и последующему волочению с многократными промежуточными термообработками (ТО) при температуре $390{ }^{\circ} \mathrm{C}$ в течение 400 и 2000 ч. После завершения ТО сверхпроводник проходил заключительное волочение со степенью деформации $e_{f i n}$. Показано, что объемная доля выделений $\alpha$-Ті-фазы увеличивается с ростом количества термических обработок вплоть до $\approx 24$ и $27 \%$ при суммарной длительности ТО 400 и 2000 ч соответственно, достигая максимальных значений при количестве ТО 4-5 и 7. Наибольший уровень плотности критического тока в магнитном поле 5 Тл $J_{c} \approx 3,8 \cdot 10^{5} \mathrm{~A} / \mathrm{cm}^{2}$ получен при общей длительности ТО 2000 ч, их количестве 7 и заключительной истинной деформации $\approx 5,05$. Зависимость объемной силы пиннинга $F_{p}$ от приведенного магнитного поля $b$ в таком сверхпроводнике описывается функцией вида $F_{p} \sim b(1-b)^{2}$, характерной для сверхпроводящих материалов с сильным пиннингом вихревой магнитной решетки на выделениях. 


\section{ВПЛИВ МЕХАНІКО-ТЕРМІЧНОЇ ОБРОБКИ НА МІКРОСТРУКТУРУ І СТРУМОНЕСУЧУ ЗДАТНІСТЬ Nb-Тi-НАДПРОВІДНИКА}

Г.С. Сторожилов, Н.Ф. Андрієвська, М.А. Тихоновський

Встановлено взаємозв'язок між режимами механіко-термічної обробки, основними параметрами мікроструктури і густиною критичного струму $J_{c}$ у надпровідному сплаві $\mathrm{Nb}-49$ мас.\% Ті. Дослідження проведені на сплаві, який піддавався попередній інтенсивній пластичній деформації (ІПД) методом «осаджування-видавлювання» і подальшому волочінню з багаторазовими проміжними термообробками (ТО) при температурі $390{ }^{\circ} \mathrm{C}$ протягом 400 і 2000 год. Показано, що об'ємна частка виділень $\alpha$-Ті-фази збільшується зі зростанням кількості термічних обробок аж до $\approx 24$ і 27\% при сумарній тривалості ТО 400 і 2000 год відповідно, досягаючи максимальних значень при кількості ТО 4-5 і 7. Найбільший рівень густини критичного струму в магнітному полі 5 Тл $J_{c} \approx 3,8 \cdot 10^{5} \mathrm{~A} / \mathrm{cm}^{2}$ отримано при загальній тривалості ТО 2000 год, їх кількості 7 і заключній істинній деформації $\approx 5,05$. Залежність об'ємної сили піннінга $F_{p}$ від наведеного магнітного поля $b$ у такому надпровіднику описується функцією виду $F_{p} \sim b(1-b)^{2}$, яка характерна для надпровідних матеріалів з сильним піннінгом вихрової магнітної решітки на виділеннях. 